 \\ International Journal of Social Sciences and Management
}

\section{A Rapid Publishing Journal}

ISSN 2091-2986

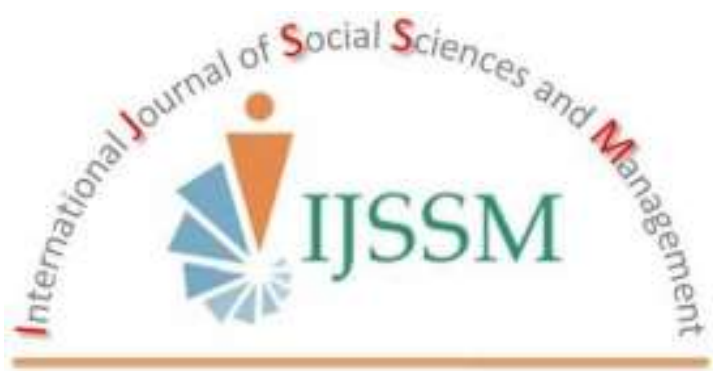

\section{Indexing and Abstracting}

CrossRef, Google Scholar, International Society of Universal Research in Sciences (EyeSource), Journal TOCs, New Jour, Scientific Indexing Services, InfoBase Index, Open Academic Journals Index (OAJI), Scholarsteer, Jour Informatics, Directory of Research Journals Indexing (DRJI), International Society for Research Activity (ISRA): Journal Impact Factor (JIF), Simon Fraser University Library, etc.

Vol-2(1) July, 2015

SEM-Biotech

Publishing

Impact factor ${ }^{*}: \mathbf{3 . 3 8 9}$ 


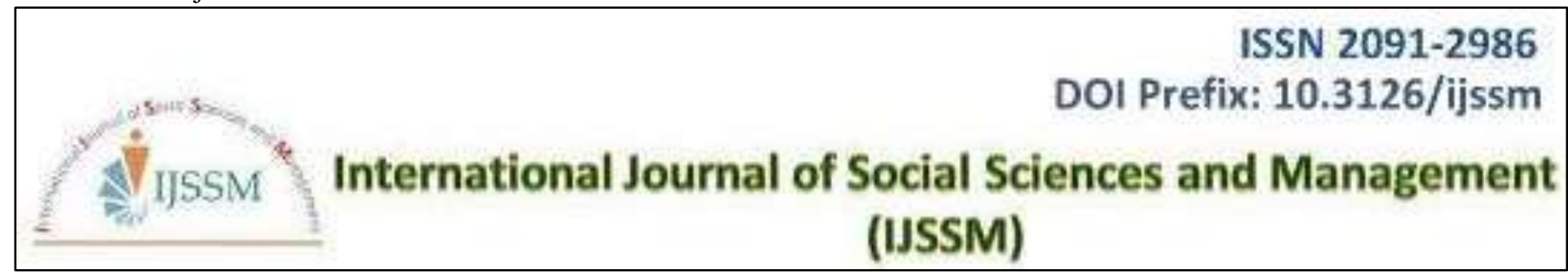

Research Article

\title{
ENTREPRENEURSHIP PERSPECTIVE FOR TRADE AND MANAGEMENT OF HORTICULTURE SECTOR IN KASHMIR HIMALAYAN VALLEY
}

\author{
Ebtisam Hanan \\ School of Business Studies, Islamic University of Sciences and Technology, Awantipora, Kashmir, India
}

Email: hananebtisam@yahoo.com

\begin{abstract}
Horticulture sector plays an extremely important role in trade and economy of Jammu and Kashmir State, India. Productivity and export of horticultural produce are vital for supplementing farm income and overall employment in the agricultural sector. J\&K State, renowned for its diverse fruits supports more than 5 lac families, and plays an important role (directly or indirectly) in the employment of nearly 25 lac people annually. Survey reports indicate that about 2.175 lac ha is under fruit crops with prospectus of bringing 1.70 lac ha more under fruit plantation crops. Apple has distinction of being principal fruit crop of the state in terms of production, and accounts for about 60-65\% of the total area of 2.95 lac hectares under all temperate fruits. Horticultural production systems hold promising and flourishing trade prospects for enthusiastic entrepreneurs, and as such warrant intense structural changes through diversification, value addition, harmonious integration of modern and indigenous know-how, organized marketing strategies and infrastructure development for the sustainable production of fruits and their processed products.
\end{abstract}

Keywords: Horticulture produce; Trade potential; Management; Himalayan Kashmir valley

\section{Introduction}

Jammu and Kashmir State, India, is renowned for its horticulture produce. The economy of the State is largely agrarian-based, and more than $60 \%$ of the population is involved in this sector. Production of 20 lac metric ton (mt) of fruits finds marketability in the entire country as well as foreign destinations. The industry generates a gross annual turnover of more than Rs.3000/- Crore and also provides employment opportunities (directly or indirectly) to about 12 lac people. The State is well known for production of apple, pear, peach, cherry, apricot, walnut, almond etc. (Anon 2008). There has been phenomenal increase in production of fruit from $1.56 \mathrm{mt}$ in 1971-72 to a record 11 lac mt during 2003-04. Areal coverage under fruit has also increased from 0.5 lac ha in 1971-72 to 11 lac ha during 2010-11. Among fruits, apple comprises of major share (82\%). The estimated marketable surplus (2011-12) of grade A and B apple is approximately 12 lac mt. Surplus grade $\mathrm{C}$ apple available for processing is $3.22 \mathrm{lac} \mathrm{mt}$, of which, about 30,000 $\mathrm{mt}$ of grade $\mathrm{C}$ and culled apples are being processed into apple concentrate by processing plants in Kashmir region. Small quantity of apple is also processed into other products, like, jam, jelly and apple preserve. Of late, the share of Kashmir apple arriving in Delhi market has declined to $42.63 \%$ during 2011-12 from $70 \%$ ten years back. This reflects a surging urge to retain apple for storage and processing. A vast natural resource base has helped the predominantly agrarian state to develop its base for cultivation of major fruits, such as apples, pear, cherry, plum, saffron, walnut and almond (Anon 2009-10). Recently, Khan (2013) presented comprehensive agriculture scenario of wide range of crops including horticulture produce in relation to environmental sustainability. More recent contribution by Wanchoo (2014) on horticulture in Himalayas specifically addresses horticulture principles and practices. Existing research report (Ahmad and Simnani, 2001) indicates that the fruit industry in Jammu and Kashmir supports more than 5 lac families and it has direct or indirect role in the employment of nearly 25 lac people annually. Furthermore, the changing lifestyle of people coupled with better income has led to increased demand for processed products. This is despite the fact that the market for processed and ready-to-eat foods is rising rapidly with a growth rate of $20 \%$ per annum. However, J\&K lags behind in industrial development, especially in food industry. Therefore, there is a vital need for well thought-out and structured strategy to accelerate the development of food processing industry in the state. There is a huge scope for the food processing industry to flourish because of the enormous availability of horticultural produce in the state. Such a scenario should attract enthusiastic entrepreneurs to take new initiatives to promote/develop horti-based industrial ventures. The activity will not only help in increasing productivity of 
agriculture and horticulture produce, but also generate employment opportunities besides exploiting the unparalleled potential of food processing sector. This communication addresses the entrepreneurship perspective for trade and management of vital horticulture sector in Kashmir Valley.

\section{Research Methodology}

Data collection was carried out both at primary and secondary level. At primary level, information was collected by interaction with selected fruit growers as part of pilot survey. Random sampling was done as per the study requirement. Secondary data was collected from official records including the Department of Horticulture J\&K, various websites, S-K University of Agriculture Sciences and Technology (SKUAST-K) and relevant documents published by concerned agencies in the form of reports, books and research publications.

\section{Results and Discussion}

\section{Data interpretation and analysis}

Data on agri-horticulture (Ahmad and Rasool, 2013) show that, presently, out of total geographical area (24.16 lac hectares), only 11.14 lac ha is available for agricultural activities; the net area sown being 7.48 lac ha. About 2.2 lac ha is reported to be under fruit crops and another 1.70 lac ha can still be brought under fruit plantation crops. Fruit production has proved vital economic activity in $\mathrm{J} \& \mathrm{~K}$ earning about 5000 Crores from fresh fruits and about 250 Crores from walnut annually. Walnut alone accounts for foreign exchange of about 130 Crores to the State However, apple is the dominating fruit crop of J\&K State in terms of production and accounts for about $60-65 \%$ of the total area of 2.95 lac hectares under all temperate fruits (Table 1). The State has emerged as the largest apple-producing region in the country with productivity as high as $19.49 \mathrm{t} \mathrm{ha}^{-1}$ in District Baramulla, Kashmir.

Wani et al. (2013) also documented (Table 2) growth of fruit production in $\mathrm{J} \& \mathrm{~K}$, and found manifold increase from 1975 to 2005.
In a recent publication Bhat and Choure (2014) reported significant increase (Table 3 ) in the production of apples in J\&K during 2004-2012, and indicates the importance of apple as outstanding commodity for fruit industry.

Table 1: Area and production of temperate fruits in Jammu \& Kashmir State (2007-08)

\begin{tabular}{llll}
\hline \multirow{2}{*}{ Kind } & $\begin{array}{l}\text { Area } \\
\text { ( ha) }\end{array}$ & $\begin{array}{l}\text { Production } \\
(\mathrm{mt})\end{array}$ & $\begin{array}{l}\text { Productivity } \\
\left(\mathrm{mt}^{\text {h ha }} \mathbf{H}^{-1}\right)\end{array}$ \\
\hline
\end{tabular}

Fresh fruit

$\begin{array}{llll}\text { Apple } & 127795 & 1311845 & 10.27 \\ \text { Pear } & 12102 & 45860 & 3.79 \\ \text { Apricot } & 4780 & 12766 & 2.67 \\ \text { Peach } & 2234 & 4256 & 1.91 \\ \text { Plum } & 3841 & 7810 & 2.03 \\ \text { Cherry } & 3137 & 10629 & 3.39 \\ \text { Grapes } & 282 & 532 & 1.89\end{array}$

\section{Dry fruits}

\begin{tabular}{llll} 
Walnut & 82045 & 146781 & 1.79 \\
Almond & 16405 & 11261 & 0.69 \\
Others & 555 & 241 & 0.43 \\
\hline
\end{tabular}

Source: Ahmad and Rasool (2013)

\section{Horticulture products: Fruit crops}

Horticulture is the core component of any processing activity. There was gradual increase in area under fruits in the state of Jammu and Kashmir with compounded annual growth rate of $3.51 \%$ during last 10 years. The state produced 15.35 lac mt of fresh fruits in the year 2009-2010. Since the production has shown a rising trend, it is expected that the present growth will be maintained in future as well. Studies indicate that about $30 \%$ of fruits produced in the state are of low grade and cull fruits. Therefore, it is estimated that there is availability of about more than 4.5 lac $\mathrm{mt}$ of low grade and cull fruits for processing. This will help in boosting the state economy of the local population.

Table 2: Growth of fruit production (mt) in Jammu and Kashmir

\begin{tabular}{llllllll}
\hline Year & Apple & Pear & Cherry & Walnut & Almond & Others & Total \\
\hline 1975 & 348011 & 953 & 436 & 15500 & 1808 & 9460 & 376168 \\
1980 & 536300 & 3200 & 530 & 15000 & 1860 & 6138 & 563028 \\
1985 & 760666 & 5257 & 569 & 13491 & 2590 & 9910 & 792483 \\
1990 & 658165 & 16665 & 4168 & 38588 & 2208 & 50159 & 769953 \\
1995 & 816050 & 25487 & 2354 & 68880 & 7158 & 48711 & 968640 \\
2000 & 909583 & 35680 & 7164 & 86263 & 9879 & 48711 & 1097280 \\
2005 & 1151712 & 42358 & 8149 & 109167 & 14327 & 87410 & 1413123 \\
\hline CGR & $3.95^{*}$ & $10.70^{*}$ & $9.71^{*}$ & $7.95^{*}$ & $9.33^{*}$ & $10.01^{*}$ & $4.49^{*}$ \\
SE & 0.34 & 1.33 & 0.80 & 0.55 & 1.06 & 0.91 & 0.30 \\
\hline DE
\end{tabular}

*Denotes significance at 0.01 level of probability (Source; Wani et al. 2013) 
The state is famous for production of valuable dry fruits like walnut and almond. The production of different dry fruits in the state was $1.78 \mathrm{lac} \mathrm{mt}$. The primary processing of these dry fruits is done at the farm level. Processing of dry fruits to value added products holds promising future, and is need of the hour.

Kashmir valley is renowned for the quality and production of apple and sustains huge population for livelihood besides earning impressive revenue for the economy of the State. In a recent publication Bhat and Choure (2014) reported significant increase (Table 3 ) in the production of apples in J\&K during 2004-2012, and indicates the importance of apple as outstanding commodity for fruit industry.

Table 3: Production of apples in Jammu \& Kashmir

\begin{tabular}{|l|l|l|}
\hline Year & $\begin{array}{l}\text { Production of Apple } \\
(\mathrm{mt})\end{array}$ & $\begin{array}{l}\text { Deviation \% } \\
( \pm)\end{array}$ \\
\hline $2004-05$ & 1093335 & - \\
\hline $2005-06$ & 1151341 & 5.30 \\
\hline $2006-07$ & 1222176 & 6.15 \\
\hline $2007-08$ & 1211845 & 7.34 \\
\hline $2008-09$ & 1332811 & 1.60 \\
\hline $2009-10$ & 1367805 & 1.70 \\
\hline $2010-11$ & 1679908.396 & - \\
\hline $\begin{array}{l}2011- \\
12 *\end{array}$ & 2581172.325 & - \\
\hline
\end{tabular}

Source: Bhat and Choure (2014)

The last five decades witnessed manifold increase in apple production. Apple, walnut and almond covering 43.30, 27.8 and $5.5 \%$ area yield $80.18,8.97$ and $0.69 \%$ production respectively. Walnut export earns about Rs.118 Crore foreign exchange. The production of almond has also shown an increase from $1808 \mathrm{mt}$ in 1975 to $11,261 \mathrm{mt}$ in 20072008. However, the productivity of almond in J\&K is far low as compared to advanced countries like USA and Australia, where productivity recorded 2.14 and $2.05 \mathrm{t} \mathrm{ha}^{-1}$ respectively (Table 4). Cherry occupies an area of about 3137 ha in J\&K with annual production of about $10629 \mathrm{mt}$ in the year of 2007-2008 with the productivity of 3.39 tha ${ }^{1}$.The major production comes from Srinagar and Pulwama districts which contribute about $56 \%$ and $31 \%$ of total production respectively. The productivity of sweet cherry is about $3.39 \mathrm{t} \mathrm{ha}^{-1}$ as compared to 6-9 $\mathrm{t} \mathrm{ha}^{-1}$ in European countries.

\section{Seasonality and raw-material availability}

The climate of Kashmir valley is characterized by distinct seasonality. Generally high temperatures prevail during summer (June-August) while severe cold conditions characterized by heavy snowfalls occur during winter (December-February). The recorded high temperature is $33^{\circ} \mathrm{C}$ and recorded low temperature is as low as $-18^{\circ} \mathrm{C}$. Kashmir valley has recorded increase in annual precipitation and relative humidity during the last few years. The average annual rainfall of Kashmir ranges from 730 to $844 \mathrm{~mm}$ per annum.

The favourable climate for production of horticultural produce is helpful to ensure uninterrupted supply of raw material for establishment of food processing units. Fruits are available during March to December in the state. The availability of fruits in Kashmir region is spread only during May to September for period of 5-6 months. Apple is the major raw material available for fruit processing unit in Jammu and Kashmir. It is available from August to November with peak production in the month of September. The harvesting season of apple extends up to the month of November. Cherry is an important fruit produced in the Kashmir. The availability of cherry is for only three months from May to July with peak production during May to June. Kashmir also grows good quality strawberry. The availability of strawberry is for only three months from May to July with peak production during May to June. Pear is harvested during July to August with peak production during July to September. The harvesting of plum takes place during July to September with peak production in the beginning of the season that is in the month of August and September. The state also grows various other fruits like mango, citrus / lime, papaya, grapes, guava, etc. These fruits can be transported to Srinagar for processing depending upon the requirement. The seasonality of fruits is a major cause of concern for any fruit processing unit. In order to ensure regular supply of raw material to the processing unit, it is imperative to set up a cold storage, and these storage facilities shall go along way for processors to extend the processing period from the present 3 months to 6 months.

\begin{tabular}{|c|c|c|c|c|c|c|c|c|}
\hline Kind of Fruit & $\mathrm{J} \& \mathrm{~K}$ & $\begin{array}{l}\text { Developed } \\
\text { countries }\end{array}$ & $\begin{array}{l}\text { Developing } \\
\text { countries }\end{array}$ & China & USA & Australia & New Zealand & India \\
\hline Apple & 10.09 & 11.02 & 9.47 & 8.17 & 23.53 & 11.80 & 38.04 & 5.68 \\
\hline Walnut & 1.39 & 2.46 & - & 1.61 & 3.16 & - & - & 1.05 \\
\hline Almond & 0.57 & 1.20 & - & 2.00 & 2.14 & 2.05 & - & - \\
\hline Cherry & 3.00 & 4.20 & 7.14 & 3.70 & 5.53 & 4.21 & 1.32 & - \\
\hline
\end{tabular}


E. Hanan (2015) Int. J. Soc. Sci. Manage. Vol-2, issue-3: 284-289

Table 5: Commodity-wise available surplus and requirement for processing in Food Park

\begin{tabular}{|l|l|l|l|l|l|l|}
\hline \multirow{2}{*}{ S.N } & \multirow{2}{*}{ Commodity } & \multirow{2}{*}{ Production $(\mathrm{mt})$} & \multicolumn{2}{|c|}{$\begin{array}{c}\text { Surplus available for } \\
\text { processing }\end{array}$} & \multirow{2}{*}{ Requirement of Mega Food Park (mt) } & $\begin{array}{l}\text { \% of } \\
\text { surplus }\end{array}$ \\
\cline { 3 - 5 } & & & $(\%)$ & $(\mathrm{mt})$ & & 2.66 \\
\hline 1 & Apple & 1749227 & 30 & 524768 & 14000 & 1.03 \\
\hline 2 & Pear & 58211 & 40 & 23284 & 241 & 2.46 \\
\hline 3 & Peach & 13497 & 30 & 4049 & 100 & 7.83 \\
\hline 4 & Apricot & 13497 & 80 & 10797 & 846 & 12.80 \\
\hline 5 & Mango & 8098 & 20 & 1619 & 208 & 0.45 \\
\hline 6 & Walnut & 224596 & 90 & 202136 & 902 & 2.8 \\
\hline 7 & Cauliflower & 27250 & 30 & 8175 & 232 & 15.75 \\
\hline 8 & Okra & 952 & 20 & 190 & 30 & 11.19 \\
\hline 9 & Garlic & 8700 & 30 & 2610 & 311 & 4.55 \\
\hline 10 & Lime/Citrus & 19734 & 30 & 5920.2 & 270 & 2.70 \\
\hline 11 & Peas & 30000 & 30 & 9000 & 243 & 4.22 \\
\hline 12 & Potato & 35525 & 30 & 10657 & 450 & 12.02 \\
\hline 13 & Leafy vegetables & 17874 & 20 & 3574 & 430 & 0.93 \\
\hline 14 & Other vegetables & 436 & 10 & 43 & 4.0 & 2.26 \\
\hline & Total & 2207597 & & 806822 & 18267 & \\
\hline
\end{tabular}

The harvesting period for walnut is only for three months. The availability is during the month of August to October with peak availability during the month of October. Almond is harvested for three months during the month of September to November with the peak production in the month of October. Both walnut and almond have better shelf-life and can be stored at ambient temperature for longer period for processing. Saffron is available during the month of October to November. The harvesting is in the alternative months during the months October, November. The peak available month is October. Though the production of dry fruits is seasonal in nature, it can be stored in a warehouse for value addition. Accordingly, warehouse for storage of raw materials is to be taken into consideration for such activity.

\section{Entrepreneurial prospectus for establishment of fruit- related activities}

The Ministry of Food Processing Industries, Government of India is playing pivotal role in promotion and development of entrepreneurial efforts to establish fruit related activities. One such activity relates to Mega Food Parks Scheme (MFPS) in India. The schemes are being implemented by the Ministry to develop Mega Food Parks in the country. The Ministry has given "In-Principle" approval to $30 \mathrm{MFP}$ projects during three phases including the one M/s RFK Greens Food Park Pvt Ltd, for implementation in the state of Jammu and Kashmir. The implementation of project will require the services of qualified engineers, skilled and unskilled labour for construction of civil structures and erection of plant and machinery. Once the Mega Food Park project is commissioned it is expected that it will generate direct and indirect employment opportunities for more than thousand people. The utilization pattern of fruits and vegetables as outlined in Mega Food Park Project J\&K, NABCONS is shown in Table 5. The food park will use only about $2.26 \%$ of the total surplus available for processing in the state.

\section{Existing marketing scenario of horticulture produce}

The relevant details related to the topic indicate that diverse marketing functionaries exist in Kashmir ranging from two important terminal centers (I each in Srinagar and Sopore) to numerous shops (1646). Apart from it, satellite markets (10), Apni Mandies (9) are conspicuous features. Likewise the number of traders is more than 3000 while significant number (> 3 lac) growers/pre-harvest contractors are worth mentioning. The early harvest (esp. apple), is marketed immediately after harvest which obviously fetches relatively better price. After harvest, fruits are kept in wooden boxes for future grading, packing and marketing. The wooden boxes are either kept in orchard or in a courtyard near residence for up to three months before marketing. Broadly speaking, two systems of trade exist in Kashmir: (a) Marketing through pre- harvest contractors and (b) Direct marketing by growers. About $70 \%$ of the fruit growers/ farmers give their orchards on contracts to pre harvest contractors for varying periods. There is role of forwarding agent which is an optional link between local contractors/growers and the Delhi buyers.

Wani et al. (2013) reported on the trends in area and production of fruits and stated that the area under fruit and 
vegetable crops has increased from 21 thousand hectares in 1960-61 to about 77 thousand hectares in 2004-05, i.e. a substantial increase of $266 \%$. Cumulative increase in area under all the fruits reflects a growth rate of $5.46 \%$ with differential growth rates in individual fruits. Growth rates barring apple and almond suggest diversified fruit based farming which is a good sign for horticultural development in the state. Since the production is strongly correlated with the area, fruit production has exhibited a tremendous growth rate ranging from 3.95 in apple to 10.70 in pear. Cherry, walnut, almond and other fruits are also reported to have shown high growth rates. High growth rates in production than in area indicate a rise in productivity levels of fruit crops especially in fruits other than apple. Since the state has a congenial atmosphere for fruit production supporting the production of various temperate and sub-tropical fruits, therefore further efforts in R \& D towards horticultural sector should lead to better returns for the state.

\section{Horticultural production and socioeconomic development}

Nain et al (2013) analyzed the entrepreneurship development through horticulture, and reported that the development of an efficient marketing network, organization of fruit growers, development of fruit mandies in main growing areas, development of entrepreneurial abilities to establish small fruit processing industries and the ability and adoption of biotechnological innovations favourable to poverty reduction will have the long lasting effect for entrepreneurship development through horticulture as well as socio-economic development. There exists an intimate relationship between horticultural production and overall socioeconomic development. An important component of horticulture sector is that it is a source of boosting agricultural business development in the rural economy and generates income and employment. Fruit growers learn to manage multiple cropping systems and deliver quality outputs in time by complying with contractual obligations and dealing with modern marketing mechanisms in place. The management skills for successful horticulture industry play vital role in take-off of socioeconomic development. Sheikh and Tripathi (2013) dealt with socio-economic conditions of apple growers of Kashmir valley and aimed at case study of district Anantnag. The study reports that it has been found that $52 \%$ of the apple growers sell their apples through wholesaler, $25 \%$ by middle man and $8 \%$ by the help of retailers. It usually depends on the productivity of the apples. According to the state's horticulture department, around 1.5 million tonnes of apples are produced in Kashmir annually. The production of apples in the state is growing every year as a result the percentage share of Jammu \& Kashmir in national production has also been increasing steadily. A recent comprehensive documentation (Anon 2013-2014) for horticulture by J\&K Govt envisages increasing production and productivity with improved quality of fruit crops along with better returns through efficient postharvesting management and promotion of value addition to horticulture crops.

Horticulture production improves availability of micronutrient rich foods whose consumption in turn improves health, learning/working capacity of people. The synergetic impact of all these factors leads to enhancement of working efficiency thereby contributing to the socioeconomic development. To this effect, the positive economic benefits of horticulture sector in Jammu and Kashmir include expansion of employment opportunities, generation of revenue (including tax revenue) to the state, generation of foreign exchange, socio-cultural effects and transformation of regional economy. Very recently, Malik (2013) provided information on assessment of apple production and marketing problems in Kashmir Valley and stated that apple production is the main occupation in the Kashmir valley and it constitutes $90 \%$ of total fruit crop in the valley. The study further assesses the potential and problems faced by this sector. The sector involving about half a million households and play a key role in the rural economy of the state, with an average annual turnover of Rs. 750 Crores. Despite this, industrial status has eluded it. Bhat and Choure (2014) dealt with the status and strength of apple industry in $\mathrm{J} \& \mathrm{~K}$, and state that apple dominates all other crops of horticulture. Rather et al (2013) explored potential and strength of Jammu and Kashmir with regard to its production and export of fresh and dry fruits. Jammu and Kashmir is the major producer of apple and walnuts in India, $77 \%$ of apple and $90 \%$ of walnut production in India belongs to Jammu and Kashmir and percentage share of state in India's total production is showing an increasing trend. J\&K state has been recently declared as 'Agri- Export Zone' for 'Apple' and 'Walnut'. As part of trade Policy under World Trade Organization (WTO), the government has passed Agricultural Produce Market Act 1997 which came into force from March,16, 2001, focused at regulating fruit and vegetable markets and to secure infrastructural development support from Government of India through various agencies, viz., National Horticulture Board (NHB), Directorate of Marketing \& Inspections (DMI), etc. Given the declining share of traditional agricultural commodities in production, consumption and trade horticulture represent an important industry to improve income growth and employment in rural areas of Jammu and Kashmir. Agribusiness including export of fresh and dry fruits is the foundation of economy. The industry contributes nearly 60 $\%$ of the states revenue and $22 \%$ of gross state domestic product. It is also estimated that $80 \%$ of population is engaged in agriculture and its allied sectors including horticulture sector in the state. 


\section{References}

Ahmad MF and Rasool FN (2013) Present scenario of temperate fruits in Jammu and Kashmir: Status and researchable issues. In: Khan MA (Ed). APH Publ. Corp. New Delhi, 346-357.

Ahmad MF and Simnani SA (2001) Temperate Horticulture in Jammu \& Kashmir: Present Status and Future Strategies. In: Jindal KK and Gautam DR (Eds) Productivity of Temperate Fruits: Issues and Strategies. Dr. Y.S. Parmar University of Horticulture \& Forestry, Solan, Himachal Pradesh, 477-486.

Anon (2008) Area and production statement for the year 2007-08. Department of Horticulture. Jammu \& Kashmir Govt.

Anon (2009-10) Economic Survey 2009-10, Directorate of Economics and Statistics, Jammu and Kashmir.

Anon (2013-14) Govt of Jammu and Kashmir RFD (ResultsFramework Document) for Horticulture (2013-2014)

Bhat TA and Choure T (2014) Status and strength of apple industry in Jammu and Kashmir. International Journal of Research 1(4): 277-283.

Khan MA (2013) Environmental Management and Sustainable Agriculture. APH Publ. Corp. New Delhi, 361 pp.
Malik ZA (2013) Assessment of apple production and marketing problems in Kashmir valley. Journal of Economic \& Social Development 9(1): 152-156.

Nain MS, Singh R, Sangeetha V, Chandel SS, Kumar P. and Peer JA (2013) Strategies for enterpreurship development through fruit production in Jammu and Kashmir State. Agricultural Scientific Digest 33(3): 165 - 171.

Rather NA, Lone PA, Reshi AA and Mir MM (2013) An analytical study on production and export of fresh and dry fruits in Jammu and Kashmir. International Journal of Scientific and Research Publications 3(2): 1-7

Sheikh SH and Tripathi AK (2013) Socio-economic conditions of apple growers of Kashmir Valley: A case study of district Anantnag. International Journal of Educational Research and Technology 4(1): 30-39.

Wanchoo PN (2014) Horticulture in Himalayas. Bishen Singh Mehendra Pal Singh, Dehra Dun, India pp.606.

Wani MH, Baba SH, Yousuf S and Saraf SA (2013) Agricultural development in retrospect and prospect In: Khan MA (Ed) Environmental Management and Sustainable Agriculture. Chapter 33, APH Publ. Corp. New Delhi, 303-315. 